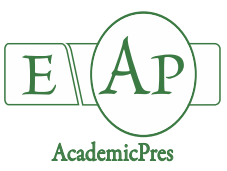

Ozsan T and Onus AN (2020)

Notulae Botanicae Horti Agrobotanici Cluj-Napoca 48(4):1873-1884

DOI:10.15835/48412089

Research Article

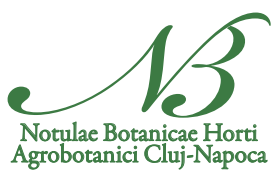

\title{
Callogenesis optimization of some globe artichoke [Cynara cardunculus var. scolymus (L.) Fiori] cultivars based on in vivo and in vitro leaf explants
}

\author{
Tugce OZSAN, Ahmet N. ONUS*
}

Akdeniz University, Faculty of Agriculture, Department of Horticulture, Dumlupınar Bulvarı, 07070 Antalya, Turkey; tugceozsan@akdeniz.edu.tr; onus@akdeniz.edu.tr ("*orresponding author)

\begin{abstract}
Globe artichoke's [Cynara cardunculus var. scolymus (L.) Fiori] leaves are rich in polyphenols and due to health-promoting properties artichoke growing has been gaining interest. Optimization and development of valuable bioactive components, which are not in the standard amount in raw material can be achieved and increased with the assistance of in vitro techniques such as callus and subsequently cell suspension cultures. Therefore, in the present study in vitro callogenesis optimization of three globe artichoke cultivars was studied by using 29 different media combinations, based on basic Gamborg B5 medium supplemented with various concentrations of 1-Naphthaleneacetic acid (NAA), 6-Benzylaminopurine (BAP), 2,4-Dichlorophenoxyacetic acid (2,4-D), and Kinetin. Comparisons were made on the basis of using in vivo and in vitro leaves as explant material. In the experiment several parameters such as leaf explants development (\%), callus formation (\%), and callus weight $(\mathrm{g})$ were assessed for each related cultivar. Results revealed that having auxin: cytokinin concentrations together at enough and well-balanced, having equal amounts or 10:1 concentrations of auxin: cytokinin, concentrations in media combinations are indispensable for stimulating the callogenesis in globe artichoke. The findings of the present study clearly revealed that, there were differences among cultivars regarding callus induction by using in vivo and in vitro leaf explants while in vivo leaf explants came into prominence regarding callus formation and weights. It is assumed that the findings of the present study may play a complementary and auxiliary role in several areas such as pharmaceutical engineering of globe artichoke.

Keywords: callus culture; callus induction; Cynara cardunculus var. scolymus (L.) Fiori; globe artichoke; in vitro; in vivo; leaf explant

\section{Introduction}

It is a well-known fact that plants have been at the service of humankind for food, health, and many other purposes. In order to ensure the adequate and balanced nutrition of world population, it has been always an aim to increase the agricultural production, quality and yield of the products by using genetic and biotechnological methods. Biotechnological applications are treasured for not only agricultural aspects but also non-nutritional purposes. Several biotechnological applications, including also callus culture technique, contribute to improvement of plants' agricultural properties.
\end{abstract}


Callus culture-based technologies offer a broad range of usage in many fields such as agriculture and pharmacology studies on industrial scale. For example, callogenesis mediates micropropagation and can enable rapid multiplication of important agricultural and horticultural cultivars. Callogenesis is also a valuable tool for generating "specialized metabolites" by virtue of containing enough homogenous and dedifferentiated cells. Additionally, callogenesis studies are thought to be beneficial for comprehending the metabolic pathways of specialized metabolite (Sa et al., 2001; Meratan et al., 2009; Tariq et al., 2014). In this content callus cultures may be utilized to generate the sustainable, large-scale, and marketable products of specialized metabolites to meet many needs of people in many fields such as food, agriculture, pharmaceutical, cosmetics, therapeutic (Espinosa-Leal et al., 2018; Efferth, 2019). The artichoke has some health-improving properties thanks to the high amount of specialized metabolites present in different parts of the plant such as heads and leaves, therefore serves as a remarkable natural antioxidant source (Pandino et al., 2012).

Plant growth regulators (PGRs) play an important role in callogenesis like in other tissue culture techniques. It is reported that when callus culture media relatively consist of high auxin and low cytokinin doses, cultured explants are induced for callogenesis (Farhan et al., 2018). Callus formation can be stimulated by virtue of the specific PGRs at appropriate concentrations, genotypes and explant types (Ananthi et al., 2011; Tariq et al., 2014).

For callogenesis auxins have been considered as essential PGRs. Among auxins, NAA and 2,4-D are generally used to promote callus formation. On the other hand, cytokinins play a crucial mission in stimulating the cell division and subsequently accelerate the process of development of calli. In this regards, BAP and kinetin come into prominence among cytokinins used in callus cultures (Lestari et al., 2019). In previous studies, researchers assessed various auxin and cytokinin combinations in different media for callus formation in several plants. Regarding artichoke callus formation, Gamborg B5 medium with BA + 2,4-D (1:10) was found to be best (Figueiredo et al., 1987; Cimino et al., 2006). In another study, it was reported that 2,4-D was effective regarding both cell development and anthocyanin biosynthesis in callus cultures of Hibiscus sabdariffa plants (Mizukami et al., 1988; Siatka, 2019). In another research, the combination of BA and NAA was more effective in phenolic accumulation than BA alone in callus cultures of Malus sieversii (Ji et al., 2015; Siatka, 2019). Previous studies conducted on artichoke clearly revealed that species, genotype, doses and types of PGRs had an influence on callus formation (Ruta et al., 2013; Joshaghani et al., 2014; Farhan et al., 2018).

In the literature studies on callus induction and formation of globe artichoke and other species were mostly conducted by using in vitro leaf explants, while the limited number of studies was carried out with in vivo leaves. To our knowledge, there are a few studies, if there is any, comparing effects of in vivo and in vitro leaf explants on callus induction and formation in globe artichoke. Thus, the present study aimed to optimize the callus induction while comparatively evaluating the response of in vivo and in vitro leaf explants to callogenesis process in globe artichoke.

\section{Materials and Methods}

\section{Plant material and surface sterilization}

Three different globe artichoke cultivars, namely open-pollinated (OP) cultivars 'Bayrampaşa' and 'Sakız' and $\mathrm{F}_{1}$ hybrid cultivar 'Olympus', were used as plant materials. In vitro and in vivo leaves were used as explant materials for callus induction and formation. To serve the purpose, special attention had been paid to collect the leaves that were newly formed and located in the innermost part of the plants. In vivo leaf explants separately collected for each cultivar were taken to the tissue culture laboratory and soil originating dirt was removed by keeping them under running tap water for 15 minutes. Afterwards in vivo leaf explants were kept in a solution of antibacterial soap ( $95 \mathrm{~mL}$ water $+5 \mathrm{~mL}$ antibacterial soap) for 15 minutes. After rinsing they were removed to laminar flow cabinets for surface sterilization which was conducted by using $20 \%$ sodium hypochlorite solution (5\% active substance) for 10 minutes, followed by 3 rinsing with sterile distilled water. 
In order to obtain in vitro leaf explants artichoke seeds were cultured in Murashige and Skoog (1962) medium (MS) with no PGRs. Before culturing the seeds were subjected to surface sterilization in a laminar flow cabinet by applying $20 \%$ sodium hypochlorite solution ( $5 \%$ active substance) for 20 minutes and rinsed with sterile distilled water 3 times. After seed germination and true leaf formation, leaves were removed and used as explant.

\section{Preparing the media, establishment of callus cultures and culture conditions}

In the present study, 29 different media (including control) combinations were used to optimize the callus formation in globe artichoke (Table 1). While Gamborg B5 (Gamborg et al., 1968) was used as the basic media supplemented with different concentrations of BAP, kinetin, 2,4-D, and NAA. Leaf explants at the size of 0.5-1.0 cm, as used in previous studies (Abbas et al., 2018; Sarmadi et al., 2018), were placed in prepared culture medium and taken to growing room conditions with $24 \pm 2{ }^{\circ} \mathrm{C}$ temperature, 16 hours light and 8 hours dark photoperiod under $3000 \mu \mathrm{E} \cdot \mathrm{m}^{-2} \cdot \mathrm{s}^{-1}$ light intensity.

Table 1. Media combinations used for callogenesis

\begin{tabular}{|c|c|c|c|c|c|c|c|}
\hline \multirow{2}{*}{$\begin{array}{l}\text { Media } \\
\text { Codes }\end{array}$} & \multirow{2}{*}{$\begin{array}{c}\text { Media - } \\
\text { Gamborg B5 } \\
\left(\mathrm{g} \mathrm{L}^{-1}\right)\end{array}$} & \multicolumn{6}{|c|}{ Media composition } \\
\hline & & $\begin{array}{c}\text { BAP } \\
\left(\mathrm{mg} \mathrm{L}^{-1}\right)\end{array}$ & $\begin{array}{c}2,4-\mathrm{D} \\
\left(\mathrm{mg} \mathrm{L}^{-1}\right)\end{array}$ & $\begin{array}{c}\mathrm{NAA} \\
\left(\mathrm{mg} \mathrm{L}^{-1}\right)\end{array}$ & $\begin{array}{c}\text { Kin } \\
\left(\mathrm{mg} \mathrm{L}^{-1}\right)\end{array}$ & $\begin{array}{c}\text { Glutamine } \\
\left(\mathrm{g} \mathrm{L}^{-1}\right)\end{array}$ & $\begin{array}{c}\text { Sucrose } \\
\left(\mathrm{g} \mathrm{L}^{-1}\right)\end{array}$ \\
\hline 1 (Control) & 3.2 & - & - & - & - & - & 30.0 \\
\hline 2 & 3.2 & 0.1 & 1.0 & - & - & - & 30.0 \\
\hline 3 & 3.2 & 0.5 & 5.0 & - & - & - & 30.0 \\
\hline 4 & 3.2 & 1.0 & 1.0 & - & - & - & 30.0 \\
\hline 5 & 3.2 & 2.0 & 2.0 & - & - & - & 30.0 \\
\hline 6 & 3.2 & 5.0 & 5.0 & - & - & - & 30.0 \\
\hline 7 & 3.2 & 0.1 & 1.0 & - & - & 1.0 & 30.0 \\
\hline 8 & 3.2 & - & 6.0 & - & 0.5 & - & 30.0 \\
\hline 9 & 3.2 & 1.0 & - & 7.0 & - & - & 30.0 \\
\hline 10 & 3.2 & 0.5 & - & 5.0 & - & - & 30.0 \\
\hline 11 & 3.2 & 5.0 & - & 5.0 & - & - & 30.0 \\
\hline 12 & 3.2 & 0.1 & - & 0.5 & - & - & 30.0 \\
\hline 13 & 3.2 & 0.1 & - & 1.0 & - & - & 30.0 \\
\hline 14 & 3.2 & 0.1 & - & 2.0 & - & - & 30.0 \\
\hline 15 & 3.2 & 0.5 & - & 0.5 & - & - & 30.0 \\
\hline 16 & 3.2 & 0.5 & - & 1.0 & - & - & 30.0 \\
\hline 17 & 3.2 & 0.5 & - & 2.0 & - & - & 30.0 \\
\hline 18 & 3.2 & 1.0 & - & 1.0 & - & - & 30.0 \\
\hline 19 & 3.2 & 1.0 & - & 2.0 & - & - & 30.0 \\
\hline 20 & 3.2 & 2.0 & - & 2.0 & - & - & 30.0 \\
\hline 21 & 3.2 & - & 0.5 & - & 0.1 & - & 30.0 \\
\hline 22 & 3.2 & - & 1.0 & - & 0.1 & - & 30.0 \\
\hline 23 & 3.2 & - & 2.0 & - & 0.1 & - & 30.0 \\
\hline 24 & 3.2 & - & 0.5 & - & 0.5 & - & 30.0 \\
\hline 25 & 3.2 & - & 1.0 & - & 0.5 & - & 30.0 \\
\hline 26 & 3.2 & - & 2.0 & - & 0.5 & - & 30.0 \\
\hline 27 & 3.2 & - & 1.0 & - & 1.0 & - & 30.0 \\
\hline 28 & 3.2 & - & 2.0 & - & 1.0 & - & 30.0 \\
\hline 29 & 3.2 & - & 2.0 & - & 2.0 & - & 30.0 \\
\hline
\end{tabular}

*Abbreviations: BAP: 6-Benzylaminopurine, 2,4-D: 2,4-Dichlorophenoxyacetic acid, NAA: 1-Naphthaleneacetic acid, Kin: Kinetin 


\section{Evaluated parameters}

Leaf explants and callus development (\%), fresh weights (g) of formed callus were assessed with nearly 30-day intervals after each subculture. A total of three subcultures were conducted to increase the amount of calli obtained. The following equations were used for determining the leaf explants development (1) and callus induction (2) percentages:

(1) Leaf explant development $(\%)=$ (number of developed leaf explants/ number of total cultured leaf explants) $\times 100$

(2) Callus induction (\%) = (number of induced callus explants/ number of developed callus explants) $\times 100$

\section{Statistical analysis}

The experiment was performed as three replicates. Three petri dishes with 20 leaf explants were used in each replicate. A total of three subcultures were conducted by using processes for both in vivo and in vitro leaf explants. At the end of three subcultures average values were calculated and obtained data were subjected to variance analysis in the JMP package program and the differences between the averages were determined by LSD test.

\section{Results}

As stated earlier the callus culture method is an in vitro culture technique that has high potential in several areas particularly pharmaceutical studies of different crops, including artichoke. In the previous studies, it was hypothesized that artichoke's leaves had high potential regarding valuable bioactive metabolites which could be used in pharmaceutics. At the beginning of the research, when we were setting up the experiments we speculated that explants originating from in vitro culture may have more tendencies to callogenesis than the in vivo leaf explants. And that is why the results and discussion were based on in the comparisons of in vitro and in vivo leaf explants as well as setting up an optimized callogenesis protocol.

\section{Effect of disinfection protocol on explants}

In present study there was no surface sterilization procedure for in vitro leaf explants since they originated from in vitro conditions and were free of any contaminants. On the other hand, special attention was given to surface sterilization of in vivo leaf explants. To serve the purpose first of all soil-based contamination sources were removed by keeping explants under running tap water. And then applying stated disinfection protocol resulted with healthy explants and that is why no serious risk of disinfection took place throughout the experiments.

\section{Evaluations of in vitro and in vivo leaf explants development}

Regarding explants types, responds of in vivo leaf explants were better than in vitro leaf explants in a comparison based on explants development among all cultivars and media combinations were tested (Table 2).

Experimental results also clearly revealed that there were statistically significant differences among cultivars in terms of explants development regardless of being in vivo or in vitro within all media combinations tested. The well responded cultivar was 'Bayrampaşa' OP, followed by 'Sakız' OP and 'Olympus' $F_{1}$, respectively.

If one considers effects of 29 media combinations, Gamborg B5 medium supplemented with $0.5 \mathrm{mg} \mathrm{L}^{-1}$ $\mathrm{BAP}+5.0 \mathrm{mg} \mathrm{L}^{-1} \mathrm{NAA}$ (medium No.10) was found to be superior to other media combinations in both explant types and for all cultivars. 
Table 2. Leaf explants development based on media combinations and cultivars (\%)

\begin{tabular}{|c|c|c|c|c|c|c|c|c|}
\hline \multirow{2}{*}{\multicolumn{2}{|c|}{$\begin{array}{c}\text { Cultivars } \\
\text { Leaf explants }\end{array}$}} & \multicolumn{2}{|c|}{ 'Bayrampaşa' OP } & \multicolumn{2}{|c|}{ 'Sakız' OP } & \multicolumn{2}{|c|}{ 'Olympus' $F_{1}$} & \multirow{2}{*}{$\begin{array}{c}\text { Mean } \\
\text { values of } \\
\text { media }\end{array}$} \\
\hline & & in vivo & in vitro & in vivo & in vitro & in vivo & in vitro & \\
\hline \multirow{29}{*}{ 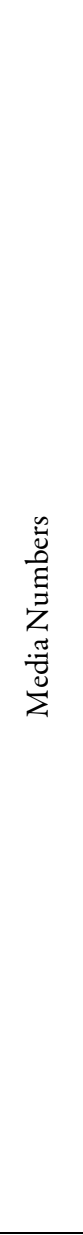 } & 1 & $22.041-x$ & $22.631-u$ & $22.221-w$ & $01-V$ & $6.651-R$ & $01-\mathrm{V}$ & $12.26 B$ \\
\hline & 2 & $38.47 \mathrm{~T}$ & $71.62 \mathrm{a}$ & $46.25 \mathrm{y}$ & $01-V$ & $57.86 n$ & $0 \mathrm{l}-\mathrm{V}$ & $35.70 E$ \\
\hline & 3 & $60.05 \mathrm{~g}$ & $45.23 \mathrm{~A}$ & $22.771-\mathrm{t}$ & $01-V$ & $34.99 \mathrm{Y}$ & $0 \mathrm{l}-\mathrm{V}$ & $27.17 O$ \\
\hline & 4 & $47.55 \mathrm{w}$ & $60.87 \mathrm{f}$ & $57.31 \mathrm{o}$ & $01-V$ & $55.27 \mathrm{p}$ & $0 \mathrm{l}-\mathrm{V}$ & $36.83 \mathrm{D}$ \\
\hline & 5 & $39.53 \mathrm{O}$ & $59.61 \mathrm{i}$ & $59.90 \mathrm{~h}$ & $11.191-\mathrm{M}$ & $58.25 \mathrm{~m}$ & $0 \mathrm{l}-\mathrm{V}$ & $38.08 B$ \\
\hline & 6 & $33.51 \mathrm{~b}$ & $40.47 \mathrm{M}$ & $61.14 \mathrm{e}$ & $0 \mathrm{l}-\mathrm{V}$ & $40.63 \mathrm{~L}$ & $11.101-\mathrm{M}$ & $31.14 \mathrm{~J}$ \\
\hline & 7 & $25.541-p$ & $58.25 \mathrm{~m}$ & $57.21 \mathrm{o}$ & $0 \mathrm{l}-\mathrm{V}$ & $48.97 \mathrm{u}$ & $0 \mathrm{l}-\mathrm{V}$ & $31.66 I$ \\
\hline & 8 & $65.61 \mathrm{~d}$ & $51.91 \mathrm{~s}$ & $39.02 \mathrm{Q}$ & $0 \mathrm{l}-\mathrm{V}$ & $22.211-w$ & $0 \mathrm{l}-\mathrm{V}$ & $29.79 \mathrm{~K}$ \\
\hline & 9 & $47.43 \mathrm{w}$ & $45.00 \mathrm{~B}$ & $69.34 \mathrm{c}$ & $0 \mathrm{l}-\mathrm{V}$ & $35.65 \mathrm{~W}$ & $01-\mathrm{V}$ & $32.90 \mathrm{~F}$ \\
\hline & 10 & $43.43 \mathrm{~F}$ & $53.74 \mathrm{q}$ & $58.85 \mathrm{k}$ & $14.451-G$ & $47.84 \mathrm{v}$ & $11.141-\mathrm{M}$ & $38.24 A$ \\
\hline & 11 & $44.45 \mathrm{C}$ & $22.441-\mathrm{v}$ & $69.54 \mathrm{~b}$ & $15.55 \mathrm{l}-\mathrm{F}$ & $59.34 \mathrm{j}$ & $16.641-\mathrm{E}$ & $37.99 C$ \\
\hline & 12 & $27.21 \mathrm{~lm}$ & $32.99 \mathrm{~d}$ & $38.27 \mathrm{U}$ & $4.48 \mathrm{l}-\mathrm{U}$ & $8.881-\mathrm{O}$ & $8.961-0$ & $20.13 Y$ \\
\hline & 13 & $4.991-\mathrm{T}$ & $41.95 \mathrm{H}$ & $38.60 \mathrm{~S}$ & $4.411-\mathrm{U}$ & $8.881-\mathrm{O}$ & $8.931-\mathrm{O}$ & $17.96 \mathrm{~A}$ \\
\hline & 14 & 18.13 l-B & $31.69 \mathrm{f}$ & $30.91 \mathrm{~g}$ & $5.571-S$ & $11.291-\mathrm{L}$ & $12.241-\mathrm{K}$ & $18.30 Z$ \\
\hline & 15 & $18.281-\mathrm{A}$ & $35.68 \mathrm{~W}$ & $43.81 \mathrm{E}$ & $13.361-\mathrm{I}$ & $13.551-\mathrm{H}$ & $19.761-z$ & $24.07 T$ \\
\hline & 16 & $6.941-Q$ & $47.24 x$ & $33.44 \mathrm{bc}$ & $6.681-R$ & $30.55 \mathrm{~h}$ & $13.561-\mathrm{H}$ & $23.07 \mathrm{~V}$ \\
\hline & 17 & $5.541-S$ & $39.28 \mathrm{P}$ & $25.531-p$ & $17.741-\mathrm{C}$ & $12.77 \mathrm{l}-\mathrm{J}$ & $8.961-0$ & $18.30 Z$ \\
\hline & 18 & $39.32 \mathrm{P}$ & $29.89 j$ & 58.681 & $6.651-R$ & $44.24 \mathrm{D}$ & $13.351-\mathrm{I}$ & $32.02 \mathrm{H}$ \\
\hline & 19 & $24.101-s$ & 29.191 & $32.94 \mathrm{~d}$ & $6.671-R$ & $52.95 \mathrm{r}$ & $17.791-C$ & $27.27 N$ \\
\hline & 20 & 17.291-D & $40.47 \mathrm{M}$ & 26.291-o & $8.881-\mathrm{O}$ & $41.65 \mathrm{I}$ & $13.351-\mathrm{I}$ & $24.65 S$ \\
\hline & 21 & $45.18 \mathrm{~A}$ & $40.70 \mathrm{~L}$ & $29.39 \mathrm{k}$ & $6.67 \mathrm{l}-\mathrm{R}$ & $22.211-\mathrm{w}$ & 13.37 l-I & $26.25 Q$ \\
\hline & 22 & $33.32 \mathrm{c}$ & $30.15 \mathrm{i}$ & $39.75 \mathrm{~N}$ & $8.871-\mathrm{O}$ & $40.88 \mathrm{~K}$ & $15.531-F$ & $28.08 \mathrm{M}$ \\
\hline & 23 & $32.77 \mathrm{e}$ & $30.22 \mathrm{i}$ & $24.551-\mathrm{q}$ & $6.671-R$ & $43.87 \mathrm{E}$ & $13.381-\mathrm{I}$ & $25.24 R$ \\
\hline & 24 & $20.101-y$ & $12.361-\mathrm{K}$ & $41.29 \mathrm{~J}$ & $5.541-S$ & $39.04 \mathrm{Q}$ & $11.091-\mathrm{M}$ & $21.57 X$ \\
\hline & 25 & $24.431-r$ & $41.66 \mathrm{I}$ & $48.95 \mathrm{u}$ & $6.671-R$ & $26.541-\mathrm{n}$ & 13.34 1-I & $26.93 P$ \\
\hline & 26 & $38.88 \mathrm{R}$ & 18.141-B & 29.231 & $8.921-0$ & $34.62 \mathrm{Z}$ & $13.351-\mathrm{I}$ & $23.86 U$ \\
\hline & 27 & $42.98 \mathrm{G}$ & $34.41 \mathrm{a}$ & $49.82 \mathrm{t}$ & 7.64 1-P & $45.66 \mathrm{z}$ & $15.561-\mathrm{F}$ & $32.68 G$ \\
\hline & 28 & $35.24 \mathrm{X}$ & $38.26 \mathrm{U}$ & $27.25 \mathrm{~lm}$ & $8.931-0$ & $10.661-\mathrm{N}$ & $15.521-\mathrm{F}$ & $22.64 \mathrm{~W}$ \\
\hline & 29 & $24.491-r$ & $37.24 \mathrm{~V}$ & $44.31 \mathrm{D}$ & $11.131-\mathrm{M}$ & $38.50 \mathrm{ST}$ & $15.561-F$ & $28.54 L$ \\
\hline \multirow{2}{*}{ 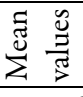 } & Cultivars & \multicolumn{7}{|c|}{ 'Bayrampaşa' OP = 35.69 A } \\
\hline & Leaf exp. & \multicolumn{7}{|c|}{ in vivo $=36.18 \mathrm{~A}$} \\
\hline \multicolumn{2}{|c|}{ LSD values } & \multicolumn{7}{|c|}{$\mathrm{LSD}_{\text {cultivar }}=0.0157$} \\
\hline
\end{tabular}

Different letters among cultivars, media compositions and leaf explants denote significant differences (LSD test, $\mathrm{p}<0.05)$.

\section{Callus formation}

Experimental results originating from callus culture revealed that the role of PGRs added to the nutrient medium greatly influenced the initial callus induction and formation. There were statistically significant differences in callus formation percentages on the basis of cultivars, leaf explants and among media combinations (Table 3). Regarding cultivars, the best callus formation percentage was obtained from 'Bayrampaşa' OP cultivar, while the medium supplemented with $0.5 \mathrm{mg} \mathrm{L}^{-1} \mathrm{BAP}+5.0 \mathrm{mg} \mathrm{L}^{-1} \mathrm{NAA}$ (medium No.10) was at the forefront among media combinations. The important point of the stated medium was to have 10:1 concentrations of auxin: cytokinin.

No callus formation was obtained by using in vitro leaf explants of 'Olympus' $F_{1}$. A similar trend was found for in vitro leaf explants of 'Sakız' OP cultivar with exceptions medium No.15 (0.5 mg L $\mathrm{L}^{-1} \mathrm{BAP}+0.5 \mathrm{mg}$ $\left.\mathrm{L}^{-1} \mathrm{NAA}\right)$ and medium No.17 (0.5 $\left.\mathrm{mg} \mathrm{L}^{-1} \mathrm{BAP}+2.0 \mathrm{mg} \mathrm{L}^{-1} \mathrm{NAA}\right)$. 
Table 3. Callus formation of leaf explants based on media combinations and cultivars (\%)

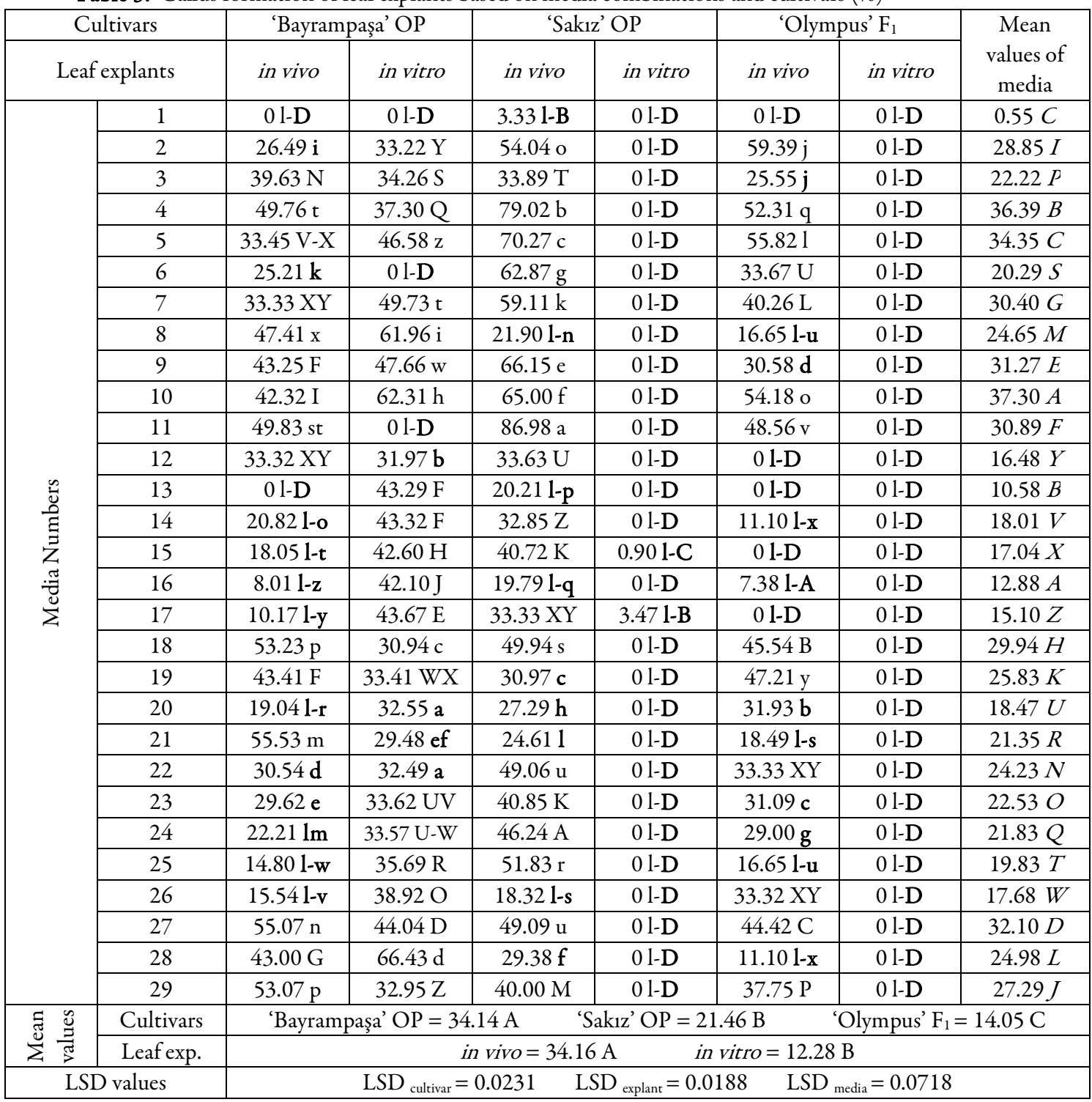

Different letters among cultivars, media compositions and leaf explants denote significant differences (LSD test, $\mathrm{p}<0.05)$.

\section{Evaluation of callus weights}

When the resulting calli were evaluated in terms of their weight, there were statistically significant differences among the cultivars, media combinations and between explant types (Table 4). The medium No.11, enriched with $5.0 \mathrm{mg} \mathrm{L}^{-1} \mathrm{BAP}+5.0 \mathrm{mg} \mathrm{L}^{-1} \mathrm{NAA}$, was the best among all 29 media combinations regarding callus weights, while in vivo leaf explants had the better result than in vitroleaf explants (Figure 1). The heaviest callus weight was obtained from in vivo leaf explants of 'Bayrampaşa' OP cultivar.

No desired results were obtained with all tested media combinations for 'Sakız' OP and 'Olympus' $F_{1}$ cultivars for in vitro leaf explants regarding callus formation and weights. 
Table 4. Callus weights of leaf explants based on media combinations and cultivars (g)

\begin{tabular}{|c|c|c|c|c|c|c|c|c|}
\hline \multirow{2}{*}{\multicolumn{2}{|c|}{$\begin{array}{c}\text { Cultivars } \\
\text { Leaf explants }\end{array}$}} & \multicolumn{2}{|c|}{ 'Bayrampaşa' OP } & \multicolumn{2}{|c|}{ ‘Sakız' OP } & \multicolumn{2}{|c|}{ 'Olympus' $F_{1}$} & \multirow{2}{*}{$\begin{array}{c}\text { Mean values } \\
\text { of media }\end{array}$} \\
\hline & & in vivo & in vitro & in vivo & in vitro & in vivo & in vitro & \\
\hline \multirow{29}{*}{ 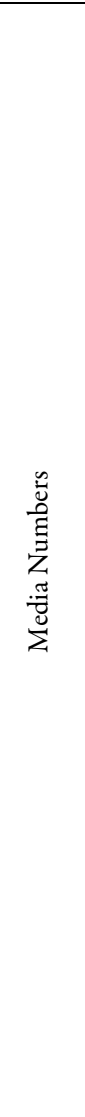 } & 1 & $0 \mathrm{~V}$ & $0 \mathrm{~V}$ & $0.008 \mathrm{UV}$ & $0 \mathrm{~V}$ & $0 \mathrm{~V}$ & $0 \mathrm{~V}$ & $0.0014 Q$ \\
\hline & 2 & $0.051 \mathrm{y}-\mathrm{F}$ & 0.183 gh & $0.066 \mathrm{vwx}$ & $0 \mathrm{~V}$ & $0.060 \mathrm{w}-\mathrm{B}$ & $0 \mathrm{~V}$ & $0.060 G$ \\
\hline & 3 & $0.060 \mathrm{w}-\mathrm{B}$ & 0.106 nop & $0.015 \mathrm{R}-\mathrm{U}$ & $0 \mathrm{~V}$ & $0.024 \mathrm{O}-\mathrm{S}$ & $0 \mathrm{~V}$ & $0.034 M N$ \\
\hline & 4 & $0.077 \mathrm{~s}-\mathrm{v}$ & $0.306 \mathrm{c}$ & $0.118 \mathrm{~lm}$ & $0 \mathrm{~V}$ & $0.045 \mathrm{D}-\mathrm{J}$ & $0 \mathrm{~V}$ & $0.091 \mathrm{D}$ \\
\hline & 5 & $0.040 \mathrm{~F}-\mathrm{L}$ & $0.176 \mathrm{~h}$ & $0.100 \mathrm{pq}$ & $0 \mathrm{~V}$ & $0.035 \mathrm{~J}-\mathrm{O}$ & $0 \mathrm{~V}$ & $0.058 G H$ \\
\hline & 6 & $0.070 \mathrm{t}-\mathrm{w}$ & $0 \mathrm{~V}$ & $0.081 \mathrm{rst}$ & $0 \mathrm{~V}$ & $0.061 \mathrm{w}-\mathrm{A}$ & $0 \mathrm{~V}$ & $0.035 M N$ \\
\hline & 7 & $0.340 \mathrm{~b}$ & $0.156 \mathrm{i}$ & $0.200 \mathrm{f}$ & $0 \mathrm{~V}$ & $0.040 \mathrm{~F}-\mathrm{L}$ & $0 \mathrm{~V}$ & $0.122 B$ \\
\hline & 8 & $0.156 \mathrm{i}$ & $0.191 \mathrm{fg}$ & $0.036 \mathrm{I}-\mathrm{N}$ & $0 \mathrm{~V}$ & $0.030 \mathrm{~L}-\mathrm{P}$ & $0 \mathrm{~V}$ & $0.069 F$ \\
\hline & 9 & $0.248 \mathrm{~d}$ & $0.114 \mathrm{mno}$ & $0.230 \mathrm{e}$ & $0 \mathrm{~V}$ & $0.087 \mathrm{rs}$ & $0 \mathrm{~V}$ & $0.113 C$ \\
\hline & 10 & $0.076 \mathrm{~s}-\mathrm{v}$ & $0.192 \mathrm{fg}$ & $0.127 \mathrm{jkl}$ & $0 \mathrm{~V}$ & $0.098 \mathrm{pq}$ & $0 \mathrm{~V}$ & $0.082 E$ \\
\hline & 11 & $0.573 \mathrm{a}$ & $0 \mathrm{~V}$ & $0.336 \mathrm{~b}$ & $0 \mathrm{~V}$ & $0.054 \mathrm{y}-\mathrm{E}$ & $0 \mathrm{~V}$ & $0.160 \mathrm{~A}$ \\
\hline & 12 & $0.048 \mathrm{C}-\mathrm{H}$ & $0.028 \mathrm{M}-\mathrm{Q}$ & $0.040 \mathrm{~F}-\mathrm{L}$ & $0 \mathrm{~V}$ & $0 \mathrm{~V}$ & $0 \mathrm{~V}$ & $0.019 P$ \\
\hline & 13 & $0 \mathrm{~V}$ & $0.068 \mathrm{uvw}$ & $0.030 \mathrm{~L}-\mathrm{P}$ & $0 \mathrm{~V}$ & $0 \mathrm{~V}$ & $0 \mathrm{~V}$ & $0.016 P$ \\
\hline & 14 & $0.036 \mathrm{I}-\mathrm{N}$ & $0.048 \mathrm{C}-\mathrm{H}$ & $0.040 \mathrm{~F}-\mathrm{L}$ & $0 \mathrm{~V}$ & $0.034 \mathrm{~J}-\mathrm{O}$ & $0 \mathrm{~V}$ & $0.026 O$ \\
\hline & 15 & $0.024 \mathrm{O}-\mathrm{S}$ & $0.061 \mathrm{w}-\mathrm{A}$ & $0.078 \mathrm{stu}$ & 0.065 wxy & $0 \mathrm{~V}$ & $0 \mathrm{~V}$ & 0.038 LM \\
\hline & 16 & $0.015 \mathrm{R}-\mathrm{U}$ & 0.064 wxy & $0.018 \mathrm{Q}-\mathrm{U}$ & $0 \mathrm{~V}$ & $0.026 \mathrm{~N}-\mathrm{R}$ & $0 \mathrm{~V}$ & $0.020 P$ \\
\hline & 17 & $0.013 \mathrm{STU}$ & 0.063 wxy & $0.034 \mathrm{~J}-\mathrm{O}$ & $0.013 \mathrm{TU}$ & $0 \mathrm{~V}$ & $0 \mathrm{~V}$ & $0.020 P$ \\
\hline & 18 & $0.090 \mathrm{qr}$ & $0.045 \mathrm{D}-\mathrm{J}$ & $0.130 \mathrm{jk}$ & $0 \mathrm{~V}$ & 0.064 wxy & $0 \mathrm{~V}$ & $0.054 H I$ \\
\hline & 19 & $0.067 \mathrm{u}-\mathrm{x}$ & $0.028 \mathrm{M}-\mathrm{Q}$ & 0.044 D-J & $0 \mathrm{~V}$ & 0.064 wxy & $0 \mathrm{~V}$ & $0.034 M N$ \\
\hline & 20 & $0.035 \mathrm{~J}-\mathrm{O}$ & $0.037 \mathrm{H}-\mathrm{M}$ & $0.045 \mathrm{D}-\mathrm{J}$ & $0 \mathrm{~V}$ & 0.043 E-J & $0 \mathrm{~V}$ & $0.026 O$ \\
\hline & 21 & $0.117 \mathrm{lmn}$ & $0.040 \mathrm{~F}-\mathrm{L}$ & $0.040 \mathrm{~F}-\mathrm{L}$ & $0 \mathrm{~V}$ & $0.050 \mathrm{~A}-\mathrm{F}$ & $0 \mathrm{~V}$ & $0.041 K L$ \\
\hline & 22 & $0.055 \mathrm{y}-\mathrm{D}$ & $0.043 \mathrm{~F}-\mathrm{K}$ & $0.120 \mathrm{klm}$ & $0 \mathrm{~V}$ & $0.054 \mathrm{y}-\mathrm{E}$ & $0 \mathrm{~V}$ & $0.045 J K$ \\
\hline & 23 & $0.048 \mathrm{C}-\mathrm{H}$ & $0.077 \mathrm{~s}-\mathrm{v}$ & $0.044 \mathrm{D}-\mathrm{J}$ & $0 \mathrm{~V}$ & $0.028 \mathrm{M}-\mathrm{Q}$ & $0 \mathrm{~V}$ & $0.033 N$ \\
\hline & 24 & 0.047 C-I & $0.055 \mathrm{y}-\mathrm{D}$ & $0.130 \mathrm{jk}$ & $0 \mathrm{~V}$ & $0.040 \mathrm{~F}-\mathrm{L}$ & $0 \mathrm{~V}$ & $0.052 I$ \\
\hline & 25 & $0.032 \mathrm{~K}-\mathrm{O}$ & $0.118 \mathrm{~lm}$ & $0.090 \mathrm{qr}$ & $0 \mathrm{~V}$ & $0.038 \mathrm{G}-\mathrm{M}$ & $0 \mathrm{~V}$ & $0.046 \mathrm{~J}$ \\
\hline & 26 & $0.077 \mathrm{~s}-\mathrm{v}$ & $0.062 \mathrm{w}-\mathrm{z}$ & $0.020 \mathrm{P}-\mathrm{T}$ & $0 \mathrm{~V}$ & $0.040 \mathrm{~F}-\mathrm{L}$ & $0 \mathrm{~V}$ & $0.033 N$ \\
\hline & 27 & $0.080 \mathrm{rst}$ & $0.049 \mathrm{~B}-\mathrm{G}$ & $0.135 \mathrm{j}$ & $0 \mathrm{~V}$ & $0.102 p$ & $0 \mathrm{~V}$ & $0.061 G$ \\
\hline & 28 & $0.056 \mathrm{x}-\mathrm{C}$ & 0.106 op & $0.040 \mathrm{~F}-\mathrm{L}$ & $0 \mathrm{~V}$ & $0.010 \mathrm{TUV}$ & $0 \mathrm{~V}$ & $0.035 M N$ \\
\hline & 29 & $0.050 \mathrm{~A}-\mathrm{F}$ & $0.041 \mathrm{~F}-\mathrm{L}$ & $0.054 \mathrm{y}-\mathrm{E}$ & $0 \mathrm{~V}$ & 0.064 wxy & $0 \mathrm{~V}$ & $0.034 M N$ \\
\hline \multirow{2}{*}{  } & Cultivars & \multicolumn{7}{|c|}{ 'Bayrampaşa' OP $=0.087 \mathrm{~A}$} \\
\hline & Leaf exp. & \multicolumn{7}{|c|}{ in vivo $=0.071 \mathrm{~A} \quad$ in vitro $=0.029 \mathrm{~B}$} \\
\hline \multicolumn{2}{|c|}{ LSD values } & \multicolumn{7}{|c|}{$L_{\text {LSD }}$ explant $=0.001188$} \\
\hline
\end{tabular}

Different letters between cultivars, media compositions and leaf explants denote significant differences (LSD test, $\mathrm{p}<0.05)$.
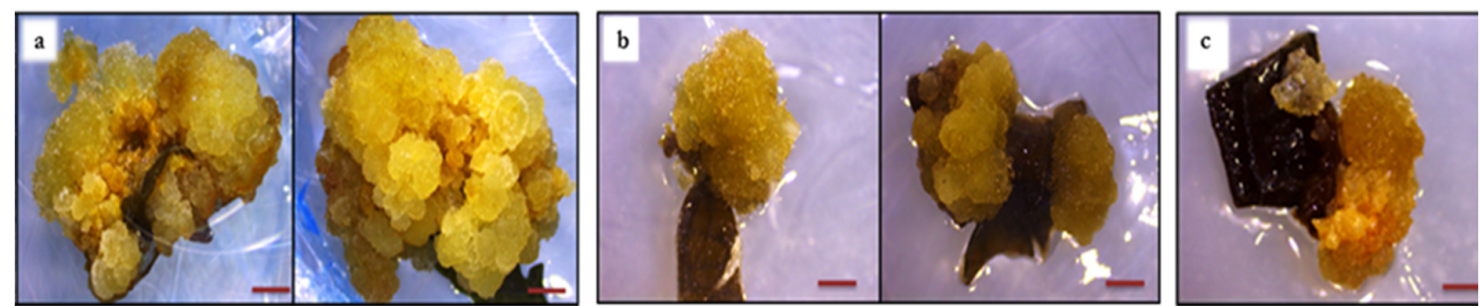

Figure 1. Callus formation of in vivo leaf explants on medium No.10; a. 'Bayrampaşa' OP, b. 'Sakız' OP; c. 'Olympus' $F_{1}$ 


\section{Discussion}

It is known that many factors are on the induction and regeneration of calli as well as secondary metabolite formation and accumulation in explants cultured in vitro. Among these factors, genotype, explant type, media composition and combination, carbohydrate source, type and concentration of PGRs, and culture conditions were reported to play an important role (Rueb et al., 1994; Shahsavari et al., 2010; Siatka, 2019).

In many studies conducted on obtaining callus on different plants, it was reported that callus could not be obtained in nutrient media without PGRs (Fiegert et al., 2000; Yasmin et al., 2003; Elaleem et al., 2009). It has also reported that cultured media should be supplemented with PGRs at the appropriate dose and combination to promote callus induction and plant regeneration, depending on genotype and explant type (Lestari et al., 2019). A number of studies have been carried out by researchers emphasizing the importance of auxins and cytokinins to get callus formation, development, and maintenance (Joshaghani et al., 2014; Baharan et al., 2015; Efferth, 2019). In the present study we also tested several PGRs at different types and concentrations and findings clearly revealed that the use of PGRs is a must for callogenesis optimization in artichoke. Findings of present study, therefore, were in agreement with previous studies (Ruta et al., 2013; Joshaghani et al., 2014; Abbas et al., 2018). It is clearly seen that PGRs play a critical role in the callogenesis process. Previous studies reported that using auxins and cytokinins together in various proportions promote callus induction, especially using varying amounts of NAA and BAP provide effective callus formation in different plants. Hesami and Daneshvar (2018) reported that they obtained maximum callus formation in the combination of $1.5 \mathrm{mg} \mathrm{L}^{-1} \mathrm{NAA}+0.15 \mathrm{mg} \mathrm{L}^{-1} \mathrm{BAP}$ in their study. Wani et al. (2018) stated that the use of in vivo leaf explants provided the best results $(83.5 \%$ callus formation rate) in the 1:1 rate of NAA + BAP combination.

Findings of the current study showed that three artichoke cultivars, regardless of explant types well responded to callogenesis in terms of callus induction in media No.10 (0.5 mg L $\mathrm{L}^{-1} \mathrm{BAP}+5.0 \mathrm{mg} \mathrm{L} \mathrm{LAA}^{-1} \mathrm{NA}$. Regarding PGRs, providing a balance between auxin and cytokinin is a necessity to achieve a successful callus formation for all three cultivars used in present study. NAA + BAP combination at 10:1 rate triggered callus induction and subsequently formation. On the other hand, NAA + BAP combination at 1:1 rate was found to be highly effective on increasing callus weights for all cultivars.

According to these findings, appropriate PGRs combinations can be alternatively used based on the purpose of study. For example, if someone wants to achieve callus induction and formation can use NAA + BAP combination at 10:1 rate. But if someone needs callus at large quantities, for example to be used in cell suspension cultures, should use NAA + BAP combination at the rate of $1: 1$.

As stated earlier one of the main aims of the present study was to evaluate the effects of in vitro and in vivo leaf explants to callogenesis in artichoke. Obtained results indicated that responses of in vivoleaf explants to callogenesis were better than in vitro leaf explants, meaning in vivoleaf explants may be preferable for further studies.

Among all 29 media combinations tested in present study medium No.7 was the only medium having glutamine. In previous plant tissue culture studies when plant cells needed, glutamine plays an alternative energy supporter role while supplying protein and nucleic acid synthesis at great number, that trigger and maintain the plant cell functions for augmenting the formation of the embryo, embryonic calli, organs, and plantlets in many plant species (Ogita et al., 2001; Newsholme et al., 2003; Vasudevan et al., 2004; Hamasaki et al., 2005; Mazri et al., 2016; Borpuzari et al., 2018). Glutamine was also successfully used as an alternative nitrogen source at various concentrations for improving in vitro carrot cell-suspension cultures (Olsen, 1987; Ozsan and Onus, 2018) and that is why we wanted to see the effects of glutamine on callus formation which is a must for cell suspension cultures. When the effects of glutamine on callus induction for all three cultivars and both explant types were examined, glutamine did not have any superior effect. On the other hand, as can be seen in Table 4 glutamine had positive effect on callus weight of 'Bayrampaşa' OP with in vivo leaf explant. 
Results may reflect that different concentrations of glutamine should be tested on various artichoke cultivars for further studies in order to clearly reveal the effects of glutamine.

For the majority of plant tissue culture studies two media have fore fronted: Murashige \& Skoog (MS) and Gamborg B5. In previous studies conducted by us using MS medium supplemented with same PGRs as indicated in material and method section failed as no callus induction and formation was obtained for three cultivars used in present study (data not shown). That is why Gamborg B5 medium was preferred in present study. There may be different reasons for Gamborg B5 medium being successful. For example, Gamborg B5 medium's inorganic nutrients concentration is less than in MS medium. In addition, these two basic media differ from each other with respect to vitamins. Gamborg B5 medium has higher concentration of thiamine than the MS medium. Thiamine takes part in cell biosynthesis and metabolism and also maintains in vitro growth (Willims, 1995; Jacob and Malpathak, 2005).

Such differences can act as trigger for callus formation from the leaf explants, which is important in terms of bioactive compounds present in leaf.

\section{Conclusions}

The findings of the present study clearly revealed that there were differences among cultivars regarding callus induction by using in vivo and in vitro leaf explants while in vivo leaf explants came into prominence regarding callus formation and weights. Among media combinations, two of them have drawn attention; 0.5 $\mathrm{mg} \mathrm{L}^{-1} \mathrm{BAP}+5.0 \mathrm{mg} \mathrm{L}^{-1} \mathrm{NAA}$ (medium No.10) and $5.0 \mathrm{mg} \mathrm{L}^{-1} \mathrm{BAP}+5.0 \mathrm{mg} \mathrm{L}^{-1} \mathrm{NAA}$ (medium No.11). But none of the media provided any callus formation for Olympus $\mathrm{F}_{1}$ when in vitroleaf explants were used; meaning different media combinations should be optimized in accordance with the cultivar used for further studies. It is assumed that the findings of the present study may guide the people working on artichoke breeding/genetics by using callogenesis and those working on pharmaceutical engineering of globe artichoke by using cell suspension cultures.

\section{Authors' Contributions}

Both authors read and approved the final manuscript.

\section{Acknowledgements}

The present study was partly funded by Akdeniz University Scientific Research Projects Coordination Unit with the project numbers FDK-2019-4611 and FBA-2019-4814. Thanks to Dr. Mehmet Ali Saridas from Cukurova University for his contribution to statistical analysis.

\section{Conflict of Interests}

The authors declare that there are no conflicts of interest related to this article. 


\section{References}

Abbas MS, El-Shabrawi HM, Soliman AS, Selim MA (2018). Optimization of germination, callus induction, and cell suspension culture of African locust beans Parkia biglobosa (Jacq.) Benth. Journal of Genetic Engineering and Biotechnology 16:191-201. https://doi.org/10.1016/j.jgeb.2017.10.012

Ananthi P, Ranjitha Kumari BD, Ramachandran A (2011). In vitro propagation of Rorippa indica L. from nodal and shoot tip explants. International Journal of Biotechnology and Molecular Biology Research 2(3):51-55.

Baharan E, Mohammadi PP, Shahbazi E, Hosseini SZ (2015). Effects of some plant growth regulators and light on callus induction and explants browning in date palm (Phoenix dactylifera L.) in vitro leaves culture. Iranian Journal of Plant Physiology 5(4):1473-1481.

Borpuzari PP, Kachari J (2018). Effect of glutamine for high frequency in vitro regeneration of Aquilaria malaccensis Lam. through nodal culture. Journal of Medicinal Plants Studies 6(2):9-16.

Cimino C, Cavalli SV, Spina F, Natalucci C, Priolo N (2006). Callus culture for biomass production of milk thistle as a potential source of milk clotting peptidases. Electronic Journal of Biotechnology 9(3):Special Issue. https://doi.org/10.2225/vol9-issue3-fulltext-14

Efferth T (2019). Biotechnology applications of plant callus cultures. Engineering 5:50-59 https://doi.org/10.1016/j.eng.2018.11.006

Elaleem KGA, Modawi RS, Khalafalla MM (2009). Effect of plant growth regulators on callus induction and plant regeneration in tuber segment culture of potato (Solanum tuberosum L.) cultivar Diamant. African Journal of Biotechnology 8(11):2529-2534.

Espinosa-Leal CA, Puente-Garza CA, Garcia-Lara S (2018). In vitro plant tissue culture: means for production of biological active compounds. Planta 248:1-18. https://doi.org/10.1007/s00425-018-2910-1

Farhan MM, Hassawi DS, Ibraheem NK (2018). Polyphenols compounds investigation of leaves and callus artichokes (Cynara scolymus L.). Plant Archives 18(2):2629-2635.

Fiegert AK, Mix WG, Vorlop KD (2000). Regeneration of Solanum tuberosum L. Tomensa cv, Induction of somatic embryogenesis in liquid culture for the production of artificial seed. Landbauforschung Volkenrode 50(3):199202.

Figueiredo AC, Fevereiro P, Cabral JMS, Novais JM, Pais MSS (1987). Callus and suspension culture for biomass production of Cynara cardunculus (Compositae). Biotechnology Letters 9(3):213-218. https://doi.org/10.1007/bf01024569

Gamborg OL, Miller RA, Ojima K (1968). Nutrient requirement of suspensions cultures of soybean root cells. Experimental Cell Research 50(1):151-158.

Hamasaki RM, Purgatto E, Mercier H (2005). Glutamine enhances competence for organogenesis in pineapple leaves cultivated in vitro. Brazilian Journal of Plant Physiology 17(4):383-389. https://doi.org/10.1590/S167704202005000400006

Hesami M, Daneshvar MH (2018). Indirect organogenesis through seedling-derived leaf segments of Ficus religiosa - a multipurpose woody medicinal plant. Journal of Crop Science and Biotechnology 21(2):129-136. https://doi.org/10.1007/s12892-018-0024-0

Jacob A, Malpathak N (2005). Manipulation of MS and B5 components for enhancement of growth and solasodine production in hairy root cultures of Solanum khasianum Clarke. Plant Cell, Tissue and Organ Culture 80:247257. https://doi.org/10.1007/s11240-004-0740-2

Ji X-H, Wang Y-T, Zhang R, Wu S-J, An M-M, Li M, ... Chen X-S (2015). Effect of auxin, cytokinin and nitrogen on anthocyanin biosynthesis in callus cultures of red-fleshed apple (Malus sieversii f.niedzwetzkyana). Plant Cell, Tissue Organ Culture 120(1):325-337.

Joshaghani MS, Ghasemnezhad A, Alizadeh M (2014). Effect of explants types, culture media and concentrations of plant growth regulator on callus induction rate in Artichoke (Cynara scolymus L.). International Journal of Biotechnology Research 2(6):70-74.

Lestari NKD, Deswiniyanti NW, Astarini IA, Arpiwi LM (2019). Callus and shoot induction of leaf culture Lilium longiflorum with NAA and BAP. Nusantara Bioscience 11(2):162-165. https://doi.org/10.13057/nusbiosci/n110209

Mazri MA, Meziani R, El Fadile J, Ezzinbi A (2016). Optimization of medium composition for in vitro shoot proliferation and growth of date palm cv. Mejhoul. 3 Biotech 6:111. https://doi.org/10.1007/s13205-016-0430-X 
Meratan AA, Ghaffari SM, Niknam V (2009). In vitro organogenesis and antioxidant enzymes activity in Acanthophyllum sordidum. Biologia Plantarum 53(1):5-10. https://doi.org/10.1007/s10535-009-0002-6

Mizukami H, Tomita K, Ohashi H, Hiraoka N (1988). Anthocyanin production in callus cultures of roselle (Hibiscus sabdariffa L.). Plant Cell Reports 7(7):553-556. https://doi.org/10.1007/BF00272755

Murashige T, Skoog F (1962) A revised medium for rapid growth and bioassays with tobacco tissue cultures. Physiologia Plantarum 15:473-497. https://doi.org/10.1111/j.1399-3054.1962.tb08052.x

Newsholme P, Lima MMR, Procopio J, Pithon-Curi TC, Doi SQ, Bazotte RB, Curi R (2003). Glutamine and glutamate as vital metabolites. Brazilian Journal of Medical and Biological Research 36:153-163. https://doi.org/10.1590/s0100-879x2003000200002

Ogita S, Sasamoto H, Yeung EC, Thorpe TA (2001). The effects of glutamine on the maintenance of embryogenic cultures of Cryptomeria japonica. In Vitro Cellular \& Developmental Biology - Plant 37:268-273. https://doi.org/10.1007/s11627-001-0048-4

Olsen FL (1987). Induction of microspore embryogenesis in cultured anthers of Hordeum vulgare. The effects of ammonium nitrate, glutamine and asparagine as nitrogen sources. Carlsberg Research Communications 52:393404.

Ozsan T, Onus AN (2018). Does glutamine promote the development of pepper (Capsicum annuum L.) anthers in vitro? Journal of Scientific and Engineering Research 5(11):228-236.

Pandino G, Lombardo S, Mauro RP, Mauromicale G (2012). Variation in polyphenol profile and head morphology among clones of globe artichoke selected from a landrace. Scientia Horticulturae 138:259-265.

Rueb S, Leneman M, Schilperoort RA, Hensgens LAM (1994). Efficient plant regeneration through somatic embryogenesis from callus induced on mature rice embryos (Oryza sativa L.). Plant Cell, Tissue and Organ Culture 36(2):259-264. https://doi.org/10.1007/BF00037729

Ruta C, Tagarelli A, Campanelli A, De Mastro G, Morone-Fortunato I (2013). Callogenesis capability of artichoke (Cynara cardunculus var. scolymus L. Fiori). In: Pagnotta MA (Ed.). Proceedings $8^{\text {th }}$ IS on Artichoke, Cardoon and Their Wild Relatives 2013. Italy: Acta Horticulturae 983 ISHS, pp 377-380. https://doi.org/10.17660/ActaHortic.2013.983.54.

Sa G, Mi M, He-chun Y, Ben-ye L, Guo-feng L, Kang C (2001). Effects of ipt gene expression on the physiological and chemical characteristics of Artemisia annua L. Plant Science 160(4):691-698. https://doi.org/10.1016/s0168-9452(00)00453-2

Sarmadi M, Karimi N, Palazón J, Ghassempour A, Mirjalili MH (2018). The effects of salicylic acid and glucose on biochemical traits and taxane production in a Taxus baccata callus culture. Plant Physiology and Biochemistry 132:271-280. https://doi.org/10.1016/j.plaphy.2018.09.013

Shahsavari E, Maheran AA, Siti Nor Akmar A, Hanafi MM (2010). The effect of plant growth regulators on optimization of tissue culture system in Malaysian upland rice. African Journal of Biotechnology 9(14):2089-2094.

Siatka T (2019). Effects of growth regulators on production of anthocyanins in callus cultures of Angelica archangelica. Natural Product Communications 2019:1-4. https://doi.org/10.1177/1934578X19857344.

Tariq U, Ali M, Abbasi BH (2014). Morphogenic and biochemical variations under different spectral lights in callus cultures of Artemisia absinthium L. Journal of Photochemistry and Photobiology B: Biology 130:264-271. https://doi.org/10.1016/j.jphotobiol.2013.11.026

Vasudevan A, Selvaraj N, Ganapathi A, Kasthurirengan S, Ramesh Anbazhagan V, Manickavasagam M (2004). Glutamine: a suitable nitrogen source for enhanced shoot multiplication in Cucumis sativus L. Biologia Plantarum 48:125-128.

Wani S, Kaloo Z, Shah M, Banday S (2018). Influence of explant and plant growth regulators on callus mediated regeneration in Lavatera cashmeriana, Cambess. Journal of Pharmacognosy and Phytochemistry 7(3):326-336. https://doi.org/10.1007/s12298-012-0146-2

Willims RR (1995). The chemical microenvironment. In: Aitken-Christie J, Kozai T, Lila Smith MA (Eds). Automation and Environmental Control in Plant Tissue Culture. Kluwer Academic Publishers, Dordrecht pp 405-439.

Yasmin S, Nasiruddin KM, Begum R, Talukder SK (2003). Regeneration and establishment of potato plantlets through callus formation with BAP and NAA. Asian Journal of Plant Sciences 2(12):936-940. https://doi.org/10.3923/ajps.2003.936.940 
Ozsan T and Onus AN (2020). Not Bot Horti Agrobo 48(4):1873-1884

OPEN ACCESS

(c) (i)

The journal offers free, immediate, and unrestricted access to peer-reviewed research and scholarly work. Users are allowed to read, download, copy, distribute, print, search, or link to the full texts of the articles, or use them for any other lawful purpose, without asking prior permission from the publisher or the author.

License - Articles published in Notulae Botanicae Horti Agrobotanici Cluj-Napoca are Open-Access, distributed under the terms and conditions of the Creative Commons Attribution (CC BY 4.0) License. (C) Articles by the authors; UASVM, Cluj-Napoca, Romania. The journal allows the author(s) to hold the copyright/to retain publishing rights without restriction. 